$\begin{array}{rr}\text { JURNAL } & \text { Volume } 10, \text { Nomor } 5 \text {, Oktober } 2014 \\ \text { FIT(1)PATOLOGI } & \text { Halaman } 160-169 \\ \text { I N D O NES I A } & \text { DOI: } 10.14692 / \text { jfi. } 10.5 .160 \\ \text { ISSN: } 0215-7950 & \end{array}$

\title{
Kompatibilitas Bacillus spp. dan Aktinomiset sebagai Agens Hayati Xanthomonas oryzae pv. oryzae dan Pemacu Pertumbuhan Padi
}

\author{
Compatibility of Bacillus spp. and Actinomycetes as \\ Biocontrol Agent for Xanthomonas oryzae pv. Oryzae and \\ Growth Promoter for Rice \\ Candra Putra, Giyanto* \\ Institut Pertanian Bogor, Bogor 16680
}

\begin{abstract}
ABSTRAK
Penyakit hawar daun bakteri merupakan salah satu penyakit penting pada tanaman padi yang disebabkan oleh bakteri Xanthomonas oryzae pv. oryzae. Bakteri ini bersifat tular benih dan bertahan dalam waktu yang lama. Beberapa mikrob diketahui berpotensi sebagai agens hayati patogen ini, seperti Bacillus spp. dan aktinomiset. Penelitian ini bertujuan mendapatkan isolat aktinomiset sebagai agens hayati $X$. oryzae pv. oryzae dan kompatibel terhadap Bacillus galur B12 yang dapat diaplikasikan pada benih padi. Aktinomiset yang diisolasi dari tanah, diseleksi dengan metode pembiakan ganda (dual culture) pada medium agar-agar dan medium tumbuh berupa tanah dan pupuk kandang $(1: 1 \mathrm{~b} / \mathrm{b})$. Enam belas aktinomiset yang berhasil diisolasi, 3 isolat memiliki sifat antagonis terhadap patogen $X$. oryzae pv oryzae dan kompatibel terhadap Bacillus galur B12, yaitu APS 7, APS 9, dan APS 12. Bacillus galur B12 dan aktinomiset diaplikasikan pada benih padi varietas Ciherang dengan metode pelapisan benih dengan bahan pembawa ialah tepung arang sekam. Perlakuan tunggal aktinomiset APS 9 dapat menekan populasi $X$. oryzae pv. oryzae $(88.89 \%)$ dan mampu memacu pertumbuhan tajuk tanaman sebesar 36.13\%. Persentase kemunculan bibit tertinggi diperoleh berturut-turut pada perlakuan kombinasi Bacillus galur B12 dan aktinomiset APS 7 (83.33\%), dan APS 9 (79.0\%) yang berbeda nyata dengan perlakuan kontrol (56.67\%). Aplikasi Bacillus galur B12 dan aktinomiset pada benih padi dapat menekan populasi $X$. oryzae pv. oryzae pada bibit padi serta meningkatkan pertumbuhan bibit padi.
\end{abstract}

Kata kunci: antagonis, hawar daun bakteri, pembiakan ganda, tular benih

\begin{abstract}
Bacterial leaf blight caused by Xanthomonas oryzae pv. oryzae is an important disease on rice. The bacteria is seed borne and survives for a long time in the seed. Some beneficial microbes, such as Bacillus spp. and actinomycetes has been reported as biocontrol agents for the disease. The objectives of the research was to select isolates of actinomycetes as biocontrol agents for X. oryzae pv. oryzae which is also compatible with Bacillus spp. by seed application. Actinomycetes isolated from soil was selected using dual culture method on agar medium and on growing medium composing of mixture of soil and manure $(1: 1 \mathrm{w} / \mathrm{w})$. Three isolates out of

\footnotetext{
*Alamat penulis korespondensi: Departemen Proteksi Tanaman, Fakultas Pertanian, Institut Pertanian Bogor, Kampus Darmaga, Jalan Kamper, Bogor

Tel: 0251-8629364, Faks: 0251-8629362, Surel: giyanto2@yahoo.com
} 
16 isolated actinomycetes, i.e. APS 7, APS 9, and APS 12 showed antagonistic activities against $X$. oryzae pv. oryzae and compatible with Bacillus spp. Both Bacillus spp. and actinomycetes was applied to rice seed variety Ciherang using seed coating method in formulation containing rice husk. Actinomycetes treatment using APS 9 isolate was able to suppress population of $X$. oryzae pv. oryzae by $(88.89 \%)$ and induce crown growth by $36.13 \%$. The highest percentage of seedling emergence was obtained on combination treatment of B12 + APS 7 and single treatment of APS 9, i.e. $83.33 \%$ and $79 \%$, respectively and significantly different with those of control treatment (56.67\%). Application of Bacillus spp. and actinomycetes on rice seed was able to suppress population of $X$. oryzae pv. oryzae on rice seedling and induce rice growth.

Key words : antagonism, bacterial leaf blight, dual culture, seed borne

\section{PENDAHULUAN}

Penyakit hawar daun bakteri merupakan salah satu penyakit penting pada tanaman padi. Penyakit ini dapat merusak tanaman mulai dari fase bibit hingga generatif. Penyakit ini disebabkan oleh bakteri Xanthomonas oryzae pv. oryzae yang dapat terbawa benih dan bertahan lama dalam benih selama fase dorman. Berbagai usaha sudah dilakukan untuk mengurangi kerugian yang ditimbulkan oleh penyakit ini, mulai dari penanaman varietas tahan hingga aplikasi bahan kimia sintetik yang bersifat toksik. Saat ini, perhatian mulai beralih ke sumber daya biologi dalam meningkatkan kesehatan dan ketahanan tanaman terhadap penyakit, antara lain melalui peran mikrob tanah yang bermanfaat.

Mikrob yang banyak diteliti ialah kelompok rizobakteria pemacu pertumbuhan tanaman (RPPT). Salah satu bakteri RPPT ialah Bacillus spp. yang merupakan bakteri gram positif pendegradasi amilum yang umumnya ditemukan di tanah. Bakteri ini memiliki kemampuan membentuk struktur bertahan berupa endospora yang memungkinkan organisme ini tahan terhadap kondisi lingkungan yang ekstrem, seperti kadar airyang rendah (Dan et al. 2012). Selain Bacillus spp., aktinomiset juga berpotensi mengendalikan mikoroorganisme penyebab penyakit, khususnya pada tanaman. Aktinomiset dikenal sebagai bakteri yang bersifat saprob dan sangat umum dijumpai di rizosfer hingga lapisan tanah dalam. Beberapa hasil penelitian menunjukkan bahwa aktinomiset merupakan kelompok mikrob yang menjanjikan untuk pengendalian biologi (Crawford et al. 1993) dan diketahui dapat menghasilkan beragam antibiotik sebagai metabolit sekundernya (Sabaratnam dan Traquair 2001).

Bacillus spp. dan aktinomiset dapat menghasilkan sporayang bertahan padakondisi ekstrem. Berdasarkan persamaan sifat ini, kedua mikrob berpotensi untuk diaplikasikan dalam suatu formulasi dengan bahan pembawa berupa tepung. Hal ini dilakukan agar dapat digunakan dengan mudah dalam pengendalian penyakit tanaman yang efektif dan aman bagi manusia serta lingkungan sekitarnya. Selain itu, mikrob dalam bahan pembawa berbentuk tepung memiliki umur simpan yang relatif lebih panjang karena mikrob berada dalam fase dorman, yaitu dalam bentuk spora yang dapat bertahan dalam waktu yang lebih lama dibandingkan dengan bentuk sel vegetatifnya.

Pembuatan suatu formulasi yang mengandung lebih dari satu jenis mikrob perlu diawali dengan kajian kompatibilitas antarmikrob tersebut. Hal ini diperlukan agar mikrob yang digunakan tidak saling meniadakan karena memiliki sifat antagonis satu sama lain. Penelitian ini bertujuan mendapatkan isolat aktinomiset sebagai agens hayati bagi patogen $X$. oryzae pv. oryzae penyebab penyakit hawar daun bakteri yang kompatibel dengan Bacillus spp. dan dapat diaplikasikan pada benih padi.

\section{BAHAN DAN METODE}

\section{Peremajaan Isolat Bacillus spp.}

Isolat Bacillus galur B12 dan X. oryzae pv. oryzae yang digunakan berasal dari koleksi Laboratorium Bakteriologi Tumbuhan, Departemen Proteksi Tanaman, Institut 
Pertanian Bogor. Isolat tersebut berupa suspensi bakteri pada larutan gliserol 20\% dan disimpan dalam keadaan beku pada suhu $-20{ }^{\circ} \mathrm{C}$. Isolat diremajakan pada medium Tryptone Soy Agar (TSA), selanjutnya cawan diinkubasi pada suhu ruang selama 1-2 hari.

\section{Isolasi dan Seleksi Aktinomiset sebagai Agens Hayati}

Aktinomiset diisolasi dari sampel tanah yang berasal dari tanah lapisan atas. Tanah dikeringanginkan pada suhu ruang selama 7-10 hari. Sebanyak $10 \mathrm{~g}$ tanah sampel disuspensikan pada $100 \mathrm{~mL}$ air steril dan diinkubasi pada inkubator bergoyang selama 15 menit. Teknik pencawanan dilakukan terhadap suspensi ini pada konsentrasi $10^{-1}-10^{-8}$. Pencawanan dilakukan pada medium semi selektif water-yeast extract agar (WYE) dan casamino acids-yeast extract-glucoseagar (YCED) (Crawford et al. 1993). Koloni aktinomiset yang tumbuh dalam waktu 7-10 hari, dimurnikan dan dijadikan sebagai isolat murni.

Seleksi aktinomiset sebagai agens hayati dilakukan dengan metode biakan ganda. Sebanyak 1 lup biakan $X$. oryzae pv. oryzae berusia 24 jam diambil dari medium yeast dextrose calcium carbonate agar (YDCA) dan diinokulasikan ke erlenmeyer berisi $10 \mathrm{~mL}$ medium Luria Broth (LB) serta diinkubasi pada inkubator bergoyang dengan kecepatan 100 rpm pada suhu ruang selama 18 jam. Pada waktu yang sama, sebanyak 1 lup spora aktinomiset, yang diperoleh dari biakan berusia 7 hari, diinokulasikan ke erlenmeyer berisi $10 \mathrm{~mL}$ medium LB dan diinkubasi pada inkubator bergoyang dengan kecepatan $100 \mathrm{rpm}$ pada suhu ruang selama $18 \mathrm{jam}$. Setelah masa inkubasi, sebanyak $100 \mu \mathrm{L}$ suspensi bakteri $X$. oryzae pv. oryzae disebar pada medium TSA, kemudian dikeringanginkan selama 15 menit pada laminar air flow cabinet. Sebanyak 4 buah kertas saring berdiameter $0.5 \mathrm{~cm}$ diletakkan pada medium TSA yang telah disebari suspensi bakteri $X$. oryzae pv. oryzae. Pada masing-masing kertas saring diteteskan $10 \mu \mathrm{L}$ suspensi aktinomiset. Setelah itu medium diinkubasi pada suhu ruang selama beberapa hari. Pengamatan terhadap aktivitas antagonisme dilakukan setiap hari. Aktivitas antagonisme ditunjukkan dengan pembentukan zona bening di sekitar kertas saring. Isolat aktinomiset yang menunjukkan sifat antagonis terhadap bakteri patogen $X$. oryzae pv. oryzae kemudian dijadikan isolat stok yang akan digunakan pada uji lanjut.

\section{Uji Kompatibilitas Bacillus Galur B12 dan Aktinomiset}

Uji kompatibilitas Bacillus galur B12 dan aktinomiset pada medium padat TSA dilakukan dengan metode biakan ganda. Sebanyak $10 \mu \mathrm{L}$ suspensi biakan aktinomiset diteteskan pada kertas saring yang terdapat pada medium agar-agar yang telah disebari susupensi Bacillus galur B12. Aktinomiset yang bersifat antagonis terhadap Bacillus spp. akan membentuk zona bening dan tidak akan digunakan sebagai bahan uji.

Tahap selanjutnya ialah uji kompatibilitas antara Bacillus galur B12 dan aktinomiset yang dilakukan pada medium tumbuh berupa tanah dan pupuk kandang $(1: 1 \mathrm{~b} / \mathrm{b})$ yang sudah disterilkan. Suspensi biakan Bacillus galur B12 dan aktinomiset dengan kepadatan $10^{5} \mathrm{cfu} \mathrm{g}^{-1}$ diinokulasikan pada medium tumbuh. Setelah diinkubasi selama 2 minggu pada suhu ruang, kepadatan populasi Bacillus spp. dan aktinomiset dihitung.

\section{Penyiapan Spora Bacillus Galur B12 dan Aktinomiset}

Produksi spora diawali dengan peremajaan biakan Bacillus galur B12 sebanyak 1 lup biakan bakteri berumur 1 hari diinokulasikan ke dalam tabung reaksi berisi $5 \mathrm{~mL}$ medium cair LB dan diinkubasi pada inkubator bergoyang dengan kecepatan 100 rpm selama 13 jam. Sebanyak $5 \mathrm{~mL}$ suspensi bakteri diinokulasi ke dalam erlenmeyer $1000 \mathrm{~mL}$ berisi $300 \mathrm{~mL}$ medium cair Dickinson dan diinkubasi pada inkubator bergoyang dengan kecepatan 100 rpm selama 6 hari. Penghitungan spora Bacillus galur B12 dilakukan dengan memanaskan suspensi pada suhu $80{ }^{\circ} \mathrm{C}$ selama 15 menit dengan tujuan untuk mematikan sel vegetatif Bacillus spp., tetapi tidak mematikan sporanya. Setelah itu, dilakukan pengenceran berseri dan dilanjutkan dengan pencawanan 
pada medium TSA. Pengamatan dilakukan dengan menghitung jumlah koloni Bacillus galur B12 yang tumbuh setelah diinkubasi selama 48 jam. Jumlah koloni yang tumbuh selanjutnya dikonversikan ke dalam satuan cfu $\mathrm{mL}^{-1}$ dengan rumus:

$$
\text { Populasi bakteri }=\frac{x}{p \times v^{2}}, \text { dengan }
$$

$x$, jumlah koloni yang tumbuh pada cawan; $p$, faktor pengenceran; $v$, volume suspensi yang disebar pada cawan.

Penyiapan aktinomiset dilakukan dengan menggoreskan kultur murni ke medium WYE atau YCED dan diinkubasi selama 8-10 hari. Spora akan tumbuh pada permukaan medium yang ditumbuhi koloni aktinomiset dengan penampakan kasar seperti beludru.

\section{Penyiapan Formula Spora Bacillus Galur B12 dan Aktinomiset pada Bahan Pembawa Tepung}

Spora Bacillus galur B12 dipanen dengan sentrifugasi menggunakan tabung plastik konikal pada $7500 \mathrm{rpm}$ pada suhu ruang selama 6 menit dari medium kultur Dickinson yang telah berumur 7 hari. Pelet yang diperoleh dicuci 2 kali dengan larutan phosphate buffer saline (PBS) $0.05 \mathrm{M} \mathrm{pH}$ 7.0. Spora bakteri yang telah dicuci diresuspensi kembali pada larutan PBS kemudian kepadatan spora bakteri pada suspensi tersebut dihitung dengan teknik pengenceran berseri.

Spora aktinomiset dipanen dari kultur aktinomiset yang telah berumur 10 hari pada cawan petri berisi medium padat. Sebanyak $10 \mathrm{~mL}$ aquades steril dituang pada cawan tersebut, kemudian dengan spatula steril koloni aktinomiset digores dengan lembut hingga sporanya lepas dari permukaan agaragar dan tersuspensi pada aquades steril. Setelah itu, suspensi spora tersebut diteteskan pada cawan kultur lain dengan menggunakan pipet. Penghitungan terhadap kepadatan spora dilakukan dengan alat haemasitometer.

Setelah dipanen, spora diinokulasikan pada bahan pembawa. Setiap bahan pembawa berukuran 50 mesh. Bahan pembawa dalam penelitian ini adalah campuran tepung arang sekam, dedak halus, tepung jagung, dan tepung cangkang udang dengan perbandingan $86.5: 3: 10: 0.5$. Bahan pembawa yang sudah dicampur kemudian dimasukkan ke dalam plastik tahan panas untuk disterilkan dalam autoklaf selama 15 menit.

Formula dibuat dengan cara menyebarkan susupensi spora bakteri dan aktinomiset secara merata pada bahan pembawa, masing-masing $5 \mathrm{~mL}$ untuk setiap $10 \mathrm{~g}$ bahan pembawa. Selanjutnya, campuran tersebut diaduk secara merata. Kepadatan spora Bacillus galur B12 dan aktinomiset yang diinokulasikan ialah

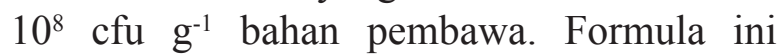
selanjutnya diletakkan pada kertas aluminium steril dan dikeringkan dalam oven pada suhu $60{ }^{\circ} \mathrm{C}$ selama 2 jam.

\section{Aplikasi Formula Agens Hayati pada Benih Padi \\ Uji dilakukan menggunakan benih padi} varietas Ciherang yang telah dianalisis menggunakan teknik pencawanan dengan pengenceran berseri untuk mengetahui infestasi awal X. oryzae pv. oryzae. Sebanyak 20 benih dipilih dan disterilkan permukaannya, lalu digerus serta disuspensikan pada $10 \mathrm{~mL}$ larutan PBS. Suspensi tersebut diencerkan hingga $10^{-8}$ kali dan disebar pada cawan berisi medium YDCA. Medium diinkubasi selama 2 hari dan $X$. oryzae pv. oryzae yang tumbuh sebagai koloni mukoid dan berwarna kuning dengan permukaan licin dihitung (Schaad et al. 2000).

Medium tanam yang digunakan berupa nampan plastik yang berisi cocopeat steril. Sebelum diberi perlakuan dan ditumbuhkan pada medium semai, benih padi direndam dalam tabung erlenmeyer steril berisi air steril selama 1 malam. Sebanyak 100 benih padi disebar pada formula bakteri yang diletakkan di atas aluminium steril dan dicampurkan secara merata hingga seluruh benih tertutupi formula bakteri. Tahap ini dinamakan pelapisan benih.

\section{Uji Formula Agens Hayati terhadap Penekanan Populasi Xanthomonas oryzae pv. oryzae}

Analisis populasi $X$. oryzae pv. oryzae dilakukan pada bibit tanaman padi yang 
berumur 7 HST. Sebanyak 20 dari 100 sampel bibit pada setiap ulangan dari setiap perlakuan digerus kemudian disuspensikan pada $50 \mathrm{~mL}$ air steril. Pencawanan $X$. oryzae pv. oryzae dilakukan pada medium YDCA. Pengamatan dilakukan dengan menghitung jumlah koloni $X$. oryzae pv. oryzae yang tumbuh setelah diinkubasi selama 48 jam. Jumlah koloni yang tumbuh selanjutnya dikonversikan ke dalam satuan cfu $\mathrm{mL}^{-1}$ dengan rumus:

$$
\text { Populasi bakteri }=\frac{x}{p \times v^{2}} \text {, dengan }
$$

$x$, jumlah koloni yang tumbuh pada cawan (cfu); $p$, faktor pengenceran; $v$, volume suspensi yang disebar pada cawan $(\mathrm{mL})$.

Uji formula agens hayati Bacillus galur B12 dan aktinomiset terhadap penekanan populasi $X$. oryzae pv. oryzae disusun dalam rancangan acak lengkap dengan 8 perlakuan (Tabel 1). Peubah yang diamati ialah jumlah koloni $X$. oryzae pv. oryzae yang tumbuh berdasarkan hasil pengenceran berseri dan pencawanan pada medium YDCA. Uji dilakukan dengan 3 ulangan. Pada setiap ulangan diambil 20 unit sampel yang dipilih secara acak yang akan dijadikan sebagai sumber pengamatan.

\section{Uji Formula Agens Hayati terhadap Pertumbuhan Bibit Padi}

Uji formula agens hayati Bacillus galur B12 dan aktinomiset terhadap pertumbuhan tanaman disusun dalam rancangan acak lengkap dengan 8 perlakuan (Tabel 1). Peubah yang diamati ialah kemunculan bibit padi dan tinggi tajuk dari bibit yang tumbuh. Uji dilakukan dengan 3 ulangan. Pada setiap ulangan diambil 20 unit sampel yang dipilih secara acak yang dijadikan sebagai sumber pengamatan.

\section{Analisis Statistik}

Data uji formulasi Bacillus galur B12 dan aktinomiset terhadap penekanan populasi $X$. oryzae pv. oryzae dan pertumbuhan tajuk pada bibit padi diolah menggunakan analisis sidik ragam (ANOVA) dengan program SAS dan uji beda nyata dilakukan pada taraf 5\%.

\section{HASIL}

\section{Isolat Bacillus Galur B12 dan Aktinomiset}

Pada medium agar-agar padat, Bacillus spp. berbentuk tidak beraturan dengan pinggiran bergerigi dan berwarna putih pucat kecokelatan. Koloni aktinomiset memiliki ciri khas berupa penampakan yang terlihat berdebu atau bertekstur seperti beludru. Penampakan tersebut merupakan spora yang dihasilkan oleh hifa aerial yang hanya dimiliki oleh aktinomiset. Hal ini berbeda dengan bakteri yang memiliki koloni mukoid ataupun permukaan licin yang khas.

Berdasarkan perbedaan fenotipe yang diamati, diperoleh 16 isolat aktinomiset dengan ciri fenotipe yang berbeda. Perbedaan ini meliputi penampakan koloni yang terbentuk pada medium agar-agar, warna koloni, serta pertumbuhan isolat tersebut dalam menghasilkan spora. Isolat aktinomiset yang tumbuh pada medium WYE ialah APS 1, APS 8, APS 9, APS 10, APS 12, APS 13, dan APS 16; sedangkan isolat yang tumbuh pada medium YCED ialah APS 2, APS 3, APS 4, APS 5, APS 6, APS 7, APS 11, APS 14, dan APS 16.

Tabel 1 Perlakuan terhadap benih padi pada pengujian formulasi spora Bacillus galur B12 dan aktinomiset

\begin{tabular}{ll}
\hline Perlakuan & Keterangan \\
\hline Kontrol & Tanpa perlakuan \\
B12 & Formulasi Bacillus galur B12 \\
APS 7 & Formulasi aktinomiset isolat APS 7 \\
APS 9 & Formulasi aktinomiset isolat APS 9 \\
APS 12 & Formulasi aktinomiset isolat APS 12 \\
B12 + APS 7 & Formulasi campuran Bacillus galur B12 dan aktinomiset isolat APS 7 \\
B12 + APS 9 & Formulasi campuran Bacillus galur B12 dan aktinomiset isolat APS 9 \\
B12 + APS 12 & Formulasi campuran Bacillus galur B12 dan aktinomiset isolat APS 12 \\
\hline
\end{tabular}


Seleksi Aktinomiset sebagai Agens Hayati

Isolat aktinomiset yang diperoleh kemudian diseleksi berdasarkan daya antagonismenya terhadap bakteri $X$. oryzae pv. oryzae. Terdapat 16 isolat aktinomiset yang berhasil diisolasi dan hanya 4 isolat yang memiliki daya hambat terhadap $X$. oryzae pv. oryzae, yaitu isolat APS 4, APS 7, APS 9, dan APS 12 (Tabel 2). Kemampuan daya hambat yang dimiliki aktinomiset diketahui dengan terbentuknya zona hambatan pada medium biakan cawan.

\section{Kompatibilitas antara Bacillus Galur B12 dan Aktinomiset}

Uji menggunakan metode biakan ganda menunjukkan bahwa satu-satunya isolat aktinomiset yang menunjukkan aktivitas antagonisme terhadap Bacillus galur B12 ialah isolat APS 4 (Tabel 3). Sebanyak 3 isolat

Tabel 2 Pembentukan zona hambatan oleh aktinomiset terhadap koloni Xanthomonas oryzae pv. oryzae pada medium tryptone soy agar

\begin{tabular}{lc}
\hline Isolat aktinomiset & $\begin{array}{c}\text { Pembentukan zona } \\
\text { bening }\end{array}$ \\
\hline APS 1 & - \\
APS 2 & - \\
APS 3 & - \\
APS 4 & - \\
APS 5 & - \\
APS 6 & + \\
APS 7 & - \\
APS 8 & + \\
APS 9 & - \\
APS 10 & - \\
APS 11 & + \\
APS 12 & - \\
APS 13 & - \\
APS 14 & - \\
APS 15 & - \\
APS 16 & - \\
\hline+ , terbentuk zona bening; - tidak terbentuk zona bening
\end{tabular}

aktinomiset yang kompatibel terhadap Bacillus galur B12, ialah isolat aktinomiset APS 7, APS 9, dan APS 12. Uji lanjut dilakukan dengan menumbuhkan masing-masing isolat aktinomiset bersama Bacillus galur B12 pada medium tanah dan pupuk kandang steril dengan masa inkubasi 3 minggu.

Berdasarkan penghitungan jumlah populasi bakteri diketahui bahwa terdapat perbedaan jumlah populasi antara bakteri yang ditumbuhkan secara tunggal dan bakteri yang ditumbuhkan secara bersamaan. Jumlah populasi Bacillus galur B12 maupun aktinomiset lebih rendah saat keduanya ditumbuhkan secara bersamaan dibandingkan dengan bila ditumbuhkan secara tunggal. Jumlah populasi Bacillus galur B12 yang ditumbuhkan bersamaan dengan APS 7 dan APS 9 lebih rendah daripada secara tunggal. Hal yang sama terjadi juga pada aktinomiset. Jumlah populasi APS 7, APS 9, dan APS 12 yang ditumbuhkan bersama dengan Bacillus galur B12 lebih rendah daripada yang ditumbuhkan secara tunggal (Gambar 1). Penurunan populasi yang terjadi dapat disebabkan oleh terjadinya kompetisi nutrisi serta ruang hidup sehingga pertumbuhan dan perkembangan bakteri ini lebih terbatas. Kompetisi ini tidak bersifat antagonis karena bakteri masih dapat tumbuh sehingga hubungan antara Bacillus spp. dan aktinomiset ini dapat dikatakan kompatibel. Populasi Bacillus galur B12 ketika ditumbuhkan bersama APS 12 mengalami peningkatan berbeda dengan dua isolat aktinomiset yang lain.

Penekanan Populasi Xanthomonas oryzae pv. oryzae dan Pertumbuhan Bibit Padi

Populasi $X$. oryzae pv. oryzae yang terbawa benih padi sebelum diberi perlakuan bakteri

Tabel 3 Pembentukan zona hambatan oleh aktinomiset terhadap koloni Bacillus galur B12 pada medium tryptone soy agar

\begin{tabular}{lcc}
\hline Isolat aktinomiset & $\begin{array}{c}\text { Pembentukan zona } \\
\text { hambatan }\end{array}$ & $\begin{array}{c}\text { Kompatibilitas terhadap Bacillus } \text { galur } \\
\text { B12 }\end{array}$ \\
\hline APS 4 & + & Tidak kompatibel \\
APS 7 & - & Kompatibel \\
APS 9 & - & Kompatibel \\
APS 12 & - & Kompatibel \\
\hline
\end{tabular}

+, terbentuk zona bening; -, tidak terbentuk zona bening 


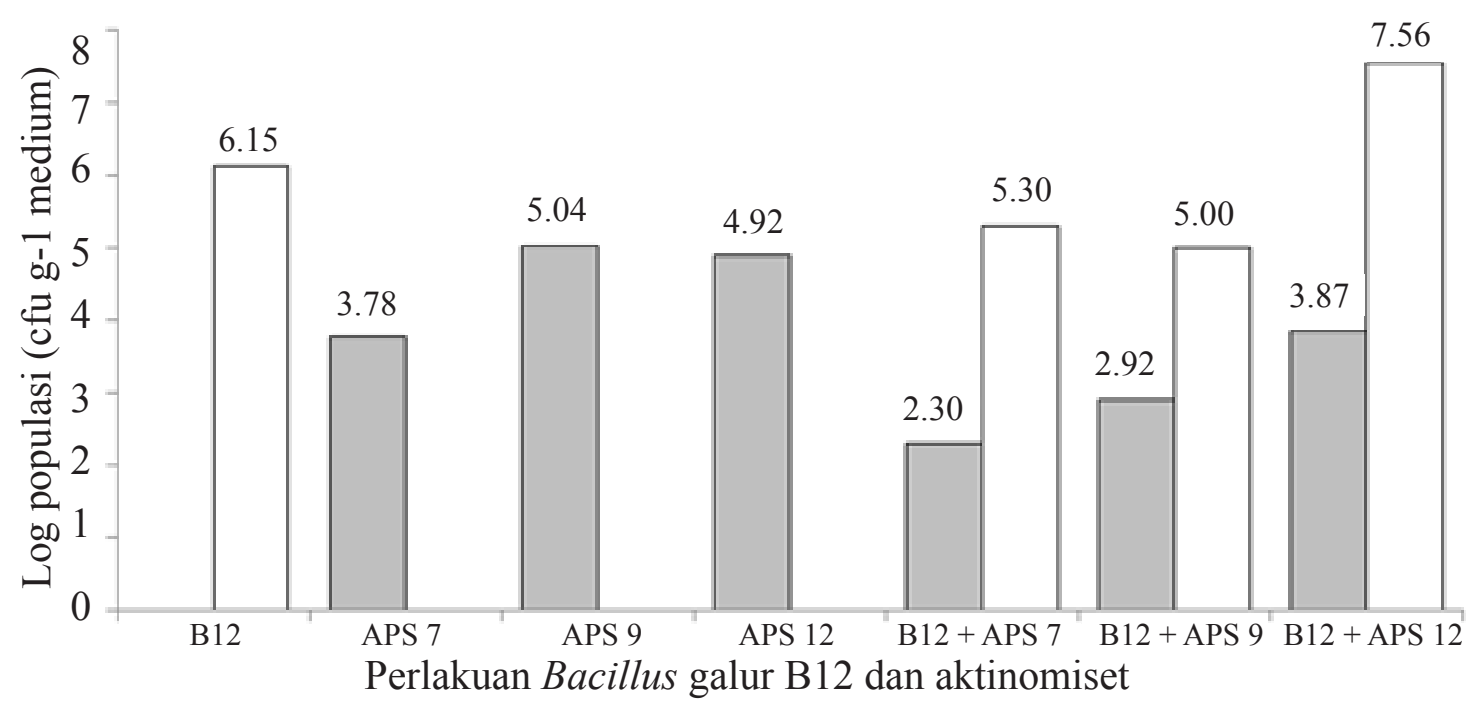

Gambar 1 Populasi Bacillus galur B12 dan aktinomiset (APS 7, APS 9, dan APS 12) pada medium campuran tanah dan pupuk kandang steril (setelah 3 minggu periode inkubasi) pada berbagai perlakuan. $\square$, aktinomiset; $\square$, Bacillus galur B12.

ialah $2.7 \times 10^{4} \mathrm{cfu} \mathrm{g}^{-1}$ benih padi. Perlakuan Bacillus galur B12 dan aktinomiset pada benih padi berpengaruh terhadap populasi bakteri patogen $X$. oryzae pv. oryzae pada bibit padi (Tabel 4). Semua perlakuan bakteri dapat menekan populasi $X$. oryzae pv. oryzae pada bibit dibandingkan dengan benih yang tidak diberi perlakuan (kontrol). Perlakuan aktinomiset isolat APS 9 dapat menekan populasi $X$. oryzae pv. oryzae sebesar $88.89 \%$. Hal ini menunjukkan adanya sifat antagonisme yang dimiliki oleh aktinomiset terhadap bakteri $X$. oryzae pv. oryzae yang terdapat pada bibit padi.

Adanya aktivitas mikrob pada benih padi menimbulkan keragaman dalam pertumbuhan bibit padi pada usia semai (Tabel 5). Perlakuan kombinasi Bacillus galur B12 dan aktinomiset isolat APS 7 (B12 + APS7) merupakan perlakuan dengan hasil paling maksimal di antara perlakuan lain. Pada 4, 5, 6, dan 7 HST sebanyak berturut-turut 20.67, 42.33, 64.67, dan $83.33 \%$ benih padi telah berkecambah. Hal ini menunjukkan adanya akivitas mikrob yang dapat memacu proses perkecambahan padi.

Perlakuan bakteri pada benih juga mengakibatkan perbedaan nyata pada tinggi tajuk bibit padi (Tabel 6). Tinggi tajuk dari benih yang tidak diberi perlakuan (kontrol) ialah $7.64 \mathrm{~cm}$, sedangkan benih yang diberi perlakuan aktinomiset isolat APS 9 memiliki tinggi tajuk paling maksimal, yaitu $10.40 \mathrm{~cm}$.

\section{PEMBAHASAN}

Bacillus merupakan bakteri gram positif yang dapat membentuk endospora yang berbentuk oval di bagian sentral sel. Endospora tersebut memungkinkan bakteri bertahan hidup pada suhu dan kondisi lingkungan yang ekstrem (Dan et al. 2012). Kemampuan bakteri ini mengolonisasi bagian rizosfer tanaman menyebabkan potensinya sangat tinggi untuk berinteraksi dengan tanaman dan berperan sebagai agens hayati dan agens pemacu pertumbuhan tanaman. Pembentukan siderofor merupakan salah satu aktivitas Bacillus sebagai agens hayati sekaligus agens pemacu pertumbuhan seperti dilaporkan oleh Dan et al. (2012) untuk B. licheniformis 9555. Chakraborty et al. (2006) juga melaporkan pada $B$. megatorium dan $B$. cereus UW85 (Husen 2003).

Aktinomiset ialah kelompok besar dari bakteri berfilamen, umumnya bersifat gram positif dan mampu menghasilkan eksospora dari ujung-ujung miselium yang terbentuk. Beberapa aktinomiset diketahui merupakan organisme endofit dan dapat diisolasi dari tanaman. Streptomyces sp. merupakan 
Tabel 4 Populasi Xanthomonas oryzae pv. oryzae pada bibit padi berumur 7 hari setelah tanam setelah perlakuan Bacillus galur B12 dan aktinomiset

\begin{tabular}{lc}
\hline Perlakuan & Populasi X. oryzae pv. oryzae $\left(\times 10^{5} \mathrm{cfu} \mathrm{g}^{-1} \mathrm{bibit}\right)$ \\
\hline Kontrol & $108.00 \mathrm{a}$ \\
Bacillus B12 & $45.33 \mathrm{c}$ \\
Aktinomiset APS 7 & $91.00 \mathrm{~b}$ \\
Aktinomiset APS 9 & $12.00 \mathrm{~d}$ \\
Aktinomiset APS 12 & $23.33 \mathrm{~d}$ \\
Bacillus B12 + aktinomiset APS 7 & $53.00 \mathrm{c}$ \\
Bacillus B12 + aktinomiset APS 9 & $16.00 \mathrm{~d}$ \\
Bacillus B12 + aktinomiset APS 12 & $48.00 \mathrm{c}$ \\
\hline Angka yang diikuti huruf yang sama tidak berbeda nyata berdasarkan uji selang berganda Duncan pada $\alpha 5 \%$
\end{tabular}

Tabel 5 Pengaruh perlakuan formulasi pada benih padi terhadap kemunculan bibit padi

\begin{tabular}{lcccc}
\hline \multirow{2}{*}{ Perlakuan } & \multicolumn{4}{c}{ Kemunculan bibit padi (\%)* } \\
\cline { 2 - 5 } Kontrol & $4 \mathrm{HST}$ & $5 \mathrm{HST}$ & $6 \mathrm{HST}$ & $7 \mathrm{HST}$ \\
Bacillus B12 & $6.67 \mathrm{~b}$ & $23.67 \mathrm{bc}$ & $40.00 \mathrm{bc}$ & $56.67 \mathrm{c}$ \\
Aktinomiset APS 7 & $6.33 \mathrm{~b}$ & $16.67 \mathrm{c}$ & $30.67 \mathrm{c}$ & $56.33 \mathrm{c}$ \\
Aktinomiset APS 9 & $20.67 \mathrm{a}$ & $35.33 \mathrm{ab}$ & $44.33 \mathrm{abc}$ & $73.33 \mathrm{abc}$ \\
Aktinomiset APS 12 & $12.67 \mathrm{ab}$ & $29.33 \mathrm{abc}$ & $58.33 \mathrm{ab}$ & $79.00 \mathrm{ab}$ \\
Bacillus B12 + aktinomiset APS 7 & $7.67 \mathrm{~b}$ & $15.67 \mathrm{c}$ & $35.67 \mathrm{bc}$ & $63.00 \mathrm{bc}$ \\
Bacillus B12 + aktinomiset APS 9 & $7.67 \mathrm{a}$ & $42.33 \mathrm{a}$ & $64.67 \mathrm{a}$ & $83.33 \mathrm{a}$ \\
Bacillus B12 + aktinomiset APS 12 & $16.00 \mathrm{~b}$ & $17.33 \mathrm{c}$ & $30.33 \mathrm{c}$ & $57.00 \mathrm{c}$ \\
*Angka yang diikuti huruf yang sama tidak berbeda nyata berdasarkan uji selang berganda Duncan pada $\alpha 5 \%$ \\
HST, hari setelah tanam
\end{tabular}

Tabel 6 Rata-rata tinggi tajuk bibit padi berumur 7 hari setelah tanam setelah perlakuan Bacillus galur B12 dan aktinomiset

\begin{tabular}{lc}
\hline Perlakuan & Tinggi tajuk $(\mathrm{cm})$ \\
\hline Kontrol & $7.64 \mathrm{e}$ \\
Bacillus B12 & $9.09 \mathrm{~cd}$ \\
Aktinomiset APS 7 & $9.89 \mathrm{abc}$ \\
Aktinomiset APS 9 & $10.40 \mathrm{a}$ \\
Aktinomiset APS 12 & $8.66 \mathrm{~d}$ \\
Bacillus B12 + aktinomiset APS 7 & $8.80 \mathrm{~d}$ \\
Bacillus B12 + aktinomiset APS 9 & $9.21 \mathrm{bcd}$ \\
Bacillus B12 + aktinomiset APS 12 & $10.07 \mathrm{ab}$ \\
\hline Anga yang diikti
\end{tabular}

Angka yang diikuti huruf yang sama tidak berbeda nyata berdasarkan uji selang berganda Duncan pada $\alpha$ 5\%

anggota aktinomisetes yang penting karena kemampuannya menghasilkan antibiotik dan salah satunya aktif menghambat pertumbuhan cendawan patogen pada tumbuhan. Aktinomisetes dilaporkan dapat mengendalikan beberapa patogen penting, seperti Rhizoctonia solani (Sabaratnam dan Traquair 2001) dan Pythium ultimum (Crawford et al. 1993). Nakaew et al. (2009) melaporkan aktinomiset Spirillospora albida menunjukkan aktivitas antimikrob terhadap Bacillus cereus, Staphylococcus aureus, dan Paenibacillus larvae.
Kombinasi aktinomiset dan Bacillus galur B12 dapat meningkatkan aktivitasnya apabila bersifat kompatibel. Aktinomiset tergolong bakteri yang aktif dalam mendegradasi bahan-bahan organik, seperti lignoselulosa, kitin, dan pati dalam tanah (Igarashi et al. 2005). Kemampuan aktinomiset dan Bacillus mendegradasi senyawa kompleks menjadi senyawa sederhana akan mempengaruhi kompatibilitas keduanya. Pada pengujian menggunakan medium tanah dan pupuk kandang, aktinomiset isolat APS 12 dan Bacillus galur B12 menunjukkan sifat 
kompatibel. Isolat APS 12 kemungkinan merupakan aktinomiset yang memiliki kemampuan mendegradasi pati yang tinggi sehingga menyediakan amilum dalam jumlah besar. Amilum merupakan senyawa turunan dari pati yang mampu dimanfaatkan oleh Bacillus galur B12 sebagai sumber nutrisi.

Bakteri patogen $X$. oryzae pv. oryzae merupakan bakteri gram negatif yang tidak dapat membentuk spora dalam siklus hidupnya. Bakteri X. oryzae pv. oryzae yang terbawa benih padi terdapat pada bagian bawah glume dan terkadang berada pada endosperma. Keberadaan bakteri pada benih dapat mengganggu proses metabolisme dari benih, diantaranya menghambat proses perkecambahan benih (Singh dan Mathur 2004). Benih padi yang tidak diberi perlakuan aktinomiset atau Bacillus galur B12 memiliki tingkat kemunculan bibit yang paling rendah. Pemberian Bacillus galur B12 maupun aktinomiset mengakibatkan terhambatnya perkembangan $X$. oryzae pv. oryzae sehingga tingkat kemunculan bibit kembali tinggi.

Perbedaan pertumbuhan kecambah padi pada berbagai perlakuan berkaitan dengan aktivitas hormon pertumbuhan yang dihasilkan oleh Bacillus galur B12 dan aktinomiset. Igarashi et al. (2005) melaporkan bahwa Streptomyces hygroscopicus S-17, salah satu anggota aktinomiset, mampu memacu pertumbuhan tomat dua kali lebih tinggi dan delapan kali lebih besar dibandingkan dengan perlakuan kontrol. Aktinomiset diketahui memproduksi toyocamicin, hormon mirip sitokinin, yang dapat memacu pertumbuhan kalus dan asam pteridat, hormon mirip auksin, yang dapat memacu perkembangan akar. Bakteri Bacillus galur B12 mampu memacu pertumbuhan tanaman karena diketahui dapat membantu tanaman menghasilkan hormon pertumbuhan seperti asam indoleasetat, asam giberelat, sitokinin, dan etilena pada tanaman (Husen 2003). Dalam jumlah yang sesuai, hormon-hormon tersebut dapat memacu pertumbuhan tanaman menjadi lebih baik.

Formulasi tepung yang mengandung Bacillus spp. dan aktinomiset berpotensi untuk digunakan dalam pengendalian penyakit hawar daun bakteri padi yang disebabkan $X$. oryzae pv. oryzae. Dari beberapa isolat aktinomiset yang diperoleh, terdapat 3 isolat yang memiliki sifat antagonis terhadap $X$. oryzae pv. oryzae dan kompatibel terhadap Bacillus spp., yaitu APS 7, APS 9, dan APS 12. Kombinasi Bacillus galur B12 dan APS7 pada benih padi mengakibatkan penekanan populasi $X$. oryzae pv. oryzae pada bibit padi dan peningkatan pertumbuhan bibit padi.

\section{DAFTAR PUSTAKA}

Chakraborty U, Chakraborty B, Basnet M. 2006. Plant growth promotion and induction of resistance in Camellia sinensis by Bacillus megaterium. J Basic Microbiol. 46:186-195. DOI: http:// dx.doi.org/10.1002/jobm.200510050.

Crawford DL, James ML, John MW, Margaret AO. 1993. Isolation and characterization of Actinomycetes antagonist of a fungal root pathogen. Appl Environ Microbiol. 11:3899-3905.

Dan VM, Mishra S, Chaudhry V, Tripathi S, Singh P, Yadav S, Mishra S, Ijinu TP, George V, Varma A, Nautiyal CS. 2012. Biocontrol, plant growth promotion and conferring stress tolerance: multifaceted role of Bacillus licheniformis 9555. Iternat J Sci Nat. 3(4):780-783.

Husen E. 2003. Screening of soil bacteria for plantgrowth promotion activities in vitro. Indon J Agric Sci. 4:27-31.

Igarashi Y, Miura S, Azumi M, Furumai T, Yoshida R. 2005. Studies on plantassociated Actinomycetes and their secondary metabolites. J Biosci Biotechnol Biochem. 21:1427-1441.

Nakaew N, Wasu P, Saisamorn L. 2009. First record of the isolation, identification and biological activity of a new strain of Spirillospora albida from Thai cave soil. Actinomycetologica. 23:1-7. DOI: http:// dx.doi.org/10.3209/saj.SAJ230102.

Sabaratnam S, Traquair JA. 2001. Formulation of a Streptomyces biocontrol agent for the suppression of rhizoctonia damping-off in tomato transplant. J Biol Control. 23:245- 
253. DOI: http://dx.doi.org/10.1006/ Singh D, Mathur SB. 2004. Histopathology bcon.2001.1014. of Seed Borne Infection. Florida Schaad NW, Jones JB, Chun W. 2000. Laboratory Guide for Identification of Plant Phatogenic Bacteria. Minnesota (US): CRC Press. DOI: http://dx.doi. org/10.1201/9781420038170.

(US): APS Press. 